\title{
Bioremediation of Crude Oil Polluted Soil Using Biofertilizer from Nitrogen-fixing and Phosphate-solubilizing Bacteria
}

\author{
Barivule Girigiri, Caroline Nchedu Ariole, Herbert Okechukwu Stanley
}

Department of Microbiology, Faculty of Science, University of Port Harcourt, Port Harcourt, Nigeria

Email address:

vulebarii@gmail.com (B. Girigiri)

\section{To cite this article:}

Barivule Girigiri, Caroline Nchedu Ariole, Herbert Okechukwu Stanley. Bioremediation of Crude Oil Polluted Soil Using Biofertilizer from Nitrogen-fixing and Phosphate-solubilizing Bacteria. American Journal of Nanosciences. Vol. 5, No. 4, 2019, pp. 27-38.

doi: $10.11648 /$ j.ajn.20190504.11

Received: October 24, 2019; Accepted: November 14, 2019; Published: November 19, 2019

\begin{abstract}
This study examined bioremediation of crude oil polluted soil (PS) stimulated with nitrogen-fixing bacteria (NFB) and phosphate-solubilizing bacteria (PSB). Five set-ups designated as A (500 g PS + 50 g NFB); B (500 g PS + 50 g PSB); C (500 g PS + 50 g NFB+PSB); D (500 g PS + 50 g NPK); and E (500 g PS only: control) were designed. Total petroleum hydrocarbons (TPHs) were monitored for 4 weeks. Toxicity of the biofertilizer on maize plant was determined. The combination of the biofertilizers with normal soil for the ecotoxicity testing was in the following ratios: 100:0, 75:25, 50:50, 25:75, and 0:100. The NFB were classified as Azotobacter sp. and Rhizobium sp. while the PSB identifies as Pseudomonas and Bacillus using their 16S rRNA gene sequences and deposited in GenBank under the accession numbers MN134485.1MN134488.1. After 28 days study, TPH reductions were $97.8 \%, 97.5 \%, 94.3 \%, 92.1 \%$, and 34.6\% in NFB, NFB+PSB, PSB, NPK treatments, and control. There was significant difference $(\mathrm{P}<0.05)$ between the set-ups when compared to the control. For toxicity testing, the 25:75 concentration in all treatment set-ups best supported plant growth. It was concluded that biofertilizer is effective in remediating oil contaminated soil and in improving soil fertility.
\end{abstract}

Keywords: Bioremediation, Nitrogen-fixing Bacteria, Phosphate-solubilizing Bacteria, Biofertilizer, Crude Oil Polluted Soil

\section{Introduction}

Biofertilizers are microbial inoculants which are artificially increased cultures of certain soil microorganisms that can enhance soil fertility and crop productivity $[1,2]$. Biofertilizers are used to stimulate indigenous hydrocarbon degrading bacteria and fungi during bioremediation [3, 4]. Nitrogen-fixing bacteria enrich the soil nutrient from oil killed microorganism and the soil itself. The bacterial genera are Clostridium, Rhizobium, Azotobacter, Azospirillum and Beijerinkia [5].

Phosphate-solubilizing bacteria can be employed for the production of biofertilizers which actually improve the nutrient quality of soil [6]. Examples of the bacterial genera are Pseudomonas, Bacillus, Flavobacteria, Aspergillus, Agrobacterium, Micrococcus, Achromobacter [7]. Nitrogenfixing bacteria release the nitrogenase enzyme system which enhances bioremediation process of crude oil polluted soil [5]. Illegal refining of crude oil and other petroleum operations in Ogoniland have negatively impacted on agricultural activities such as farming and fishing, thereby increasing poverty in the region.

The use of inorganic fertilizer (e.g. NPK) to enhance bioremediation, poses environmental and ecological challenges [8]. There is need to employ remediation techniques that will restore contaminated media (e.g. soil) to a state that can be used for agricultural and other important activities. The use of biofertilizer reduces the rate of environmental pollution. Commercial feasibility of biofertilizer production could have a price fall effects on chemical fertilizer. The processes facilitate soil enrichment and promote plants' growth. It is also a sustainable and environmentally friendly approach to the remediation of hydrocarbon polluted media. It increases microbial 
populations in the soil by enhancing hydrocarbon utilizing bacteria. This research, therefore, seeks to investigate the use of nitrogen-fixing and phosphate-solubilizing bacteria for bioremediation of crude oil polluted soil in Kegbara-Dere (KDere), Gokana Local Government Area of Rivers State and to further determine the toxicity level of the biofertilizer that support remediated soil.

\section{Materials and Methods}

\subsection{Sample Collection}

The polluted soil was sourced from Barabeedom eastern zone of Kegbara-Dere (K-Dere) in Ogoni-land which is located close to Bomu manifold flow station in connection with Trans-Niger pipeline, which transports crude oil through Ogoniland to Bonny trunk line. The nearest farmland and river are polluted because of oil spillfrom pipeline leakage. Co-ordinates of sampled points were determined usingGlobal Positioning System (GPS).

The co-ordinates of sampled point are: Latitude: 4.671768, Longitude: 7.253275 and point B are: latitude: 4.675735, Longitude: 7.251268. Soil samples were source with aid of soil auger from polluted areas at Barabeedom of K-Dere, Gokana L. G. A. Five random samples $(500 \mathrm{~g})$ each was collected at depth of $0-15 \mathrm{~cm}$ and another five samples were collected at depth of $15-30 \mathrm{~cm}$ and sieved through a $4.5 \mathrm{~mm}$ mesh sieve. The ten soil samples were homogenized to make a composite sample then packaged in sterile container and immediately transported to laboratory. The test seed (maize) were collected in polythene bags from rural farmers.

\subsection{Microcosm Set-up}

Approximately $1.5 \mathrm{~kg}$ of soil was placed in plastic vessel labeled A, B; C and D (Table 1). The $150 \mathrm{~g}$ polluted soil (PS) containing $10 \%$ crude oil was left undisturbed for $48 \mathrm{~h}$. After these time, $10 \%$ of each bio-fertilizer namely Nitrogen-fixing bacteria (NFB), Phosphate-solubilizing bacteria (PSB) and $\mathrm{NFB}+\mathrm{PSB}$ were supplemented into each oil-polluted soil labeled $\mathrm{A}, \mathrm{B}$ and $\mathrm{C}$ and mixed. Vessel $\mathrm{D}$ served as control with only soil and crude oil. Also, additional control (comprising autoclaved soil and $0.5 \% \mathrm{NaN}_{3}$ ) in vessel D1 was placed to observe degradation process of crude oil in soil arising from non-biological factors.

The moisture was attuned to $60 \%$ by adding water, and content were tilled for aeration 3 times every week for 4 weeks. The plastic vessel was then hatched at $30 \pm 2{ }^{\circ} \mathrm{C}$ in three places. Samples collected were moved to laboratory for analyses within 2 weeks time interval $\left(14^{\text {th }}\right.$ and $28^{\text {th }}$ day). Bioremediation for hydrocarbons in different experiments were monitored using standard recommended methods of analysis [9]. Table 1 show the experimental design.

Table 1. Experiment Design

\begin{tabular}{ll}
\hline Set-up & Treatment Content \\
\hline Set A & $500 \mathrm{~g}$ PS (autoclaved) $+50 \mathrm{~g} \mathrm{NFB}(10 \%)$ \\
Set B & $500 \mathrm{~g}$ PS (autoclaved) $+50 \mathrm{~g} \mathrm{PSB}(10 \%)$ \\
Set C & $500 \mathrm{~g}$ PS (autoclaved) $+50 \mathrm{~g} \mathrm{NFB}(10 \%)+$ PSB $(10 \%)$ \\
Set D (Control) & $500 \mathrm{~g}$ PS (autoclaved) $+50 \mathrm{~g} \mathrm{~N} . \mathrm{P} . \mathrm{K}$ \\
Set $\mathrm{D}_{1}$ & $500 \mathrm{~g}$ PS (autoclaved) + no amendment \\
\hline
\end{tabular}

PS: Polluted soil, NFB: Nitrogen-fixing bacteria, PSB: Phosphate-solubilizing bacteria.

\subsection{Toxicity Test}

A total of fifteen polythene vessels were employed. The set-up for each test-plant included one positive control (normal soil) and four vessels of varying concentrations of the biofertilizer. Each polythene vessel was contained specific quantity of soil and the respective quantity of the bio-fertilizers in ratio: $4: 0 ; 3: 1 ; 2: 2 ; 1: 3$ and $0: 4$. For each of these test-plants, experiment was conducted with various biofertilizers (phosphate-solubilizing bacterial bio-fertilizer, Nitrogen-fixing bacterial bio-fertilizer, and mixture of phosphate-solubilizing and Nitrogen-fixing bacterial). The experiment took 14 days ( 2 weeks) and plants monitored for seed germination, leaf coloration and root elongation.

\subsection{Enumeration of Microorganisms}

Soil slurry was prepared and used for the preparation of a 10 -fold serial dilution by mixing $1 \mathrm{~g}$ of wet soil with $9 \mathrm{ml}$ of sterile physiological saline suspension in a test tube. Subsequently serial dilution from that test tube was performed starting from $10^{-1}$ to obtain $10^{-7}$ dilution.
Determinations of counts of the various physiological groups of bacteria were carried out in triplicates and counts obtained expressed as colony forming units per gram (CFU/g) of soil.

\subsubsection{Enumeration of Total Heterotrophic Bacteria}

Total culturable heterotrophic bacteria in soil were enumerated on nutrient agar which comprised the following: meat extract $1 \mathrm{~g}$, yeast extract $2 \mathrm{~g}$; peptone $5 \mathrm{~g}, \mathrm{NaCl} 25 \mathrm{~g}$, agar No. 2 powder $15 \mathrm{~g}$, and distilled water 1 litre. The final $\mathrm{pH}$ was 7.4 \pm 0.2 . Nitrogen-fixing bacteria were isolated from the soil samples using the method employed by Ogugbue et al. [10]

\subsubsection{Enumeration of Phosphate-Solubilizing Bacteria}

The prepared Pikovskaya medium for isolation was sterilized and autoclaved using temperature at $121^{\circ} \mathrm{C}$ for fifteen minutes. The medium was placed in petri-plates and given time to solidify. About 0.1 millimeter of polluted soil solution was spread on plate by spread-plate technique. The plates are then incubated in 5 to 7 days at $37^{\circ} \mathrm{C}$ [11]. After 5 to 7 days incubation resulted in growths. Dilution $10^{-3}$ and $10^{-4}$ were selected for screening halo zone formation around 
colonies. Screening of phosphate-solubilizing bacteria was carried out using bromocresol green as indicator for dye utilization and preliminary screening positioned at $37^{\circ} \mathrm{C}$ for 12 days.

The green color zone that produce isolates were specified as phosphate-solubilizes in solid culture conditions. The obvious halo zone was evaluated by withholding their colony diameter. To ascertain whether these isolates were phosphatesolubilizers they were tested for their acetylene reduction activity assay in liquid culture.

\subsubsection{Enumeration of Nitrogen-fixing Bacteria}

Individual nitrogen-fixing microbes was separated or isolated by spread plating on nitrogen free enrichment media. Exactly $0.5 \mathrm{~mL}$ part of these samples was pipetted and plated on solid medium. Glass spreader was sterilized using alcohol and flamed before using then in spreading the inoculums on the plates and were incubated at room temperature, purity was accomplished by sub-culturing continually on nutrient agar which was prepared by dissolving $2.8 \mathrm{~g}$ nutrient agar in $100 \mathrm{~mL}$ distilled water then autoclaved in $121^{\circ} \mathrm{C}$ within fifteen minutes.

Screening for nitrogen-fixing bacteria was done using nitrogen free malate media [12], containing bromothymol blue as an indicator was used in primary screening and incubation at $37^{\circ} \mathrm{C}$ up to $24 \mathrm{~h}$. Blue color area producing isolates were specified as nitrogen fixers in solid culture conditions. The colouring area was evaluated by deducting colony size from colouring zone size. To ascertain whether these isolates are nitrogen fixers, they were also tested for "acetylene reduction activity assay" in liquid culture.

\subsubsection{Enumeration of Hydrocarbon Utilizing Bacteria}

Hydrocarbon utilizing bacteria in soil samples were enumerated using a modified mineral salt medium of Mills. It contained: $\mathrm{MgSO}_{4} .7 \mathrm{H}_{2} \mathrm{O} 0.40 \mathrm{~g} ; \mathrm{KCl}, 0.28 \mathrm{~g} ; \mathrm{KH}_{2} \mathrm{PO}_{4} 0.80 \mathrm{~g}$; $\mathrm{Na}_{2} \mathrm{HPO}_{4} 1.20 \mathrm{~g} ; \mathrm{NH}_{4} \mathrm{NO}_{3} 0.40 \mathrm{~g} ; \mathrm{NaCl} 15 \mathrm{~g}$ and agar No. 2 powder $20 \mathrm{~g}$, all in 1 liter of de-ionized water. The $\mathrm{pH}$ of the medium was adjusted to 7.1 and subsequently sterilized at $121^{\circ} \mathrm{C}$ for $15 \mathrm{~min}$.

Crude oil was introduced to the medium through vapour phase transfer by soaking a $9 \mathrm{~cm}$ Whatman No. 1 filter paper with $10 \mathrm{ml}$ of fresh Bonny light crude oil. The flooded filter paper was then placed on the lid of the agar plate and incubated for 7 days at $25 \pm 8^{\circ} \mathrm{C}$ in an inverted position [13]. The filter papers served as a source of energy and carbon and supplied the hydrocarbons by vapour-phase transfer to inverted inoculums.

\subsection{Characterization of Isolates}

Colonies of nitrogen-fixing bacteria and hydrocarbon utilizing bacteria were picked randomly using a sterile inoculating wire loop and purified by sub-culturing on nutrient agar plates. The plates were incubated at $28 \pm 2^{\circ} \mathrm{C}$ for $24 \mathrm{~h}$ to obtain pure colonies. Gram reaction, cell arrangement, colonial morphology and biochemical characteristics of purified colonies were examined. Gram- negative, grayish, mucoid and flat colonies with a pearshaped suggestive of Nitrobacter were picked and identified with reference to Bergey's Manual of Systematic Bacteriology by Holt et al. [14]. The physicochemical properties were also used to characterize the isolates. The total organic carbon, moisture content, phosphate, sulphate and nitrate contents were determined using standard methods. The $\mathrm{pH}$ was analysed with $\mathrm{pH}$ meter (Jenway 3015) and the residualtotal petroleum hydrocarbon in the soil was determined using a modified EPA 8015 technique. All analyses were carried out in triplicates.

\subsection{Statistical Analysis}

At the end of this research, the data generated were compared with result from positive control soil $[15,16]$. The data sourced from this analysis are analyzed using SPSS version 20.0 for one-way ANOVA to ascertain significant difference between mean values at $\mathrm{P}<0.05$ and correlation coefficient.

\section{Results}

The changes in population of the various physiological groups of bacteria in the treated soil during the study period are as presented in Table 2, figures 1-21 respectively. The baseline microbiological and physiochemical properties of the polluted soil (PS) are shown in Table 2. TPH and THCin these un-modified polluted soils were $8987.5742 \pm 0.00$ and $6000 \pm 0.00 \mathrm{mg} / \mathrm{kg}$ respectively. $\mathrm{pH}$ was observed as acidic at $\mathrm{pH} 6.5 \pm 0.169$. Temperature was $28 \pm 0.6^{\circ} \mathrm{C}$; moisture, 0.16 $\pm 0.01 \%$. Electrical conductivity was $3.6 \pm 0.25 \mu \mathrm{S} / \mathrm{cm}$ while nitrate, phosphate and sulphate contents were $86.2 \pm 0.35 \mathrm{mg} / \mathrm{kg}, \quad 34.8 \pm 0.7 \mathrm{mg} / \mathrm{kg}$ and $24.1 \pm 0.5 \mathrm{mg} / \mathrm{kg}$, respectively.

The baseline analyses for microbiological parameters (Total heterotrophic bacteria (THB), hydrocarbons using bacteria (HUB) and nitrogen fixing bacteria (NFB) showed thatTHB had count of $1.58 \times 10^{7} \pm 0.205$ while HUB and NFB counts were $7.9 \times 10^{4} \pm 0.170$ and $7.4 \times$ $10^{4} \pm 0.162 \mathrm{CFU} / \mathrm{g}$ respectively. Figure 1: THBC was 7.12 $\log _{10} \mathrm{cfu} / \mathrm{g}$ in Site A while in Site B it was 5.82 $\log _{10} \mathrm{cfu} / \mathrm{g}$. HUBC was 4.7 and $4.9 \log _{10} \mathrm{cfu} / \mathrm{g}$ in site $\mathrm{A}$ (Artisanal refinery site) and $\mathrm{B}$ (Polluted farmland) respectively. TABC was fairly the same in both samples (5.12 and $5.25 \log _{10} \mathrm{cfu} / \mathrm{g}$ ).

NFBC was 4.87 and 4.209 $\log _{10}$ cfu/g while the PSBC was 4.73 and $4.88 \log _{10} \mathrm{cfu} /$ gin Site A and Site B respectively. The result presented in Table 3 revealed the compositions of the bio-fertilizer after Nitrate concentration were noticed as $6.27 \mathrm{mg} / \mathrm{kg}$, Phosphate was $0.029 \mathrm{mg} / \mathrm{kg}$. $\mathrm{pH}$ and Temperature were 8.5 and $28^{\circ} \mathrm{C}$ while total nitrogen and organic matter were $15.6 \mathrm{mg} / \mathrm{kg}$ and $40 \mathrm{mg} / \mathrm{kg}$ respectively. Table 2 is a summary of all the physicochemical and microbiological parameters of crude oil contaminated soil before bioremediation. The $\mathrm{pH}$ of experimental set up modified using NFB varied slightly from 7.52 to 7.41 on $14^{\text {th }}$ 
day and finally 7.24 on $28^{\text {th }}$ day while $\mathrm{pH}$ of PSB-modified reduced from 7.45 to 7.38 on $14^{\text {th }}$ day and finally to 7.21 . $\mathrm{NFB}+\mathrm{PSB}$ amended samples had decreased $\mathrm{pH}$ from 7.84 to
6.85 on $28^{\text {th }}$ day. However, control set up had decreased $\mathrm{pH}$ from 6.54 to 4.81 .

Table 2. Physicochemical and Microbiological parametersof crude oil contaminated soil before bioremediation.

\begin{tabular}{lll}
\hline Parameters & Unit & Values \pm S. D \\
\hline Temperature & ${ }^{\circ} \mathrm{C}$ & $28 \pm 0.6$ \\
Nitrate & $\mathrm{mg} / \mathrm{kg}$ & $86.2 \pm 0.35$ \\
Phosphate & $\mathrm{mg} / \mathrm{kg}$ & $34.8 \pm 0.7$ \\
Sulphate & $\mathrm{mg} / \mathrm{kg}$ & $24.1 \pm 0.5$ \\
Moisture & $\%$ & $0.16 \pm 0.01$ \\
$\mathrm{pH}$ & & $6.5 \pm 0.169$ \\
TOC & $\%$ & $14.18 \pm 0.337$ \\
THC & $\mathrm{mg} / \mathrm{kg}$ & $6000 \pm 0.00$ \\
TPH & $\mathrm{mg} / \mathrm{kg}$ & $8987.5742 \pm 0.00$ \\
TH & $\mathrm{CFU} / \mathrm{g}$ & $1.58 \times 10^{7} \pm 0.205$ \\
HUB & $\mathrm{CFU} / \mathrm{g}$ & $7.9 \times 10^{4} \pm 0.170$ \\
NFB & $\mathrm{CFU} / \mathrm{g}$ & $7.4 \times 10^{4} \pm 0.162$ \\
\hline
\end{tabular}

Results are expressed as mean \pm standard deviation

The result presented in Figure 3 revealed a decline in nitrate concentration during bioremediation study. Firstly, the set up modified using NPK revealed decline in nitrate concentration from $252.91 \mathrm{mg} / \mathrm{kg}$ on zero day to 127.12 $\mathrm{mg} / \mathrm{kg}$ on $14^{\text {th }}$ day then $70.53 \mathrm{mg} / \mathrm{kg}$.

In experiment modified using nitrogen- fixing and phosphorous solubilizing bacterial suspension, nitrate content decreased from $143.91 \mathrm{mg} / \mathrm{kg}$ on initial day to $127.12 \mathrm{mg} / \mathrm{kg}$ on the $14^{\text {th }}$ day and further declined to $18.99 \mathrm{mg} / \mathrm{kg}$. In set up modified using phosphate solubilizing bacterial suspension, the nitrate content dropped from $164.18 \mathrm{mg} / \mathrm{kg}$ on initial day to $69.03 \mathrm{mg} / \mathrm{kg}$ then to $30.43 \mathrm{mg} / \mathrm{kg}$ on $28^{\text {th }}$ day. The result shown in Figure 4 describes alteration in $\mathrm{pH}$ content of the treatments. The results presented in Figure 5 revealed 293.46 $\mathrm{mg} / \mathrm{kg}$ on the initial day and then $134.05 \mathrm{mg} / \mathrm{kg}$ on $14^{\text {th }}$ day and $70.468 \mathrm{mg} / \mathrm{kg}$ on $28^{\text {th }}$ day.

PSB-amended sample had total nitrogen concentration of $180.09 \mathrm{mg} / \mathrm{kg}$. Samples amended with NFB+PSB declined from $561.36 \mathrm{mg} / \mathrm{kg}$ to $310.05 \mathrm{mg} / \mathrm{kg}$ on day 14 then to 83.16 $\mathrm{mg} / \mathrm{kg}$ on $28^{\text {th }}$ day. NPK-amended samples increased from $168.05 \mathrm{mg} / \mathrm{kg}$ to $199.07 \mathrm{mg} / \mathrm{kg}$. The control had value of 27.9 $\mathrm{mg} / \mathrm{kg}$ initially and $29.2 \mathrm{mg} / \mathrm{kg}$ on 14 th day.

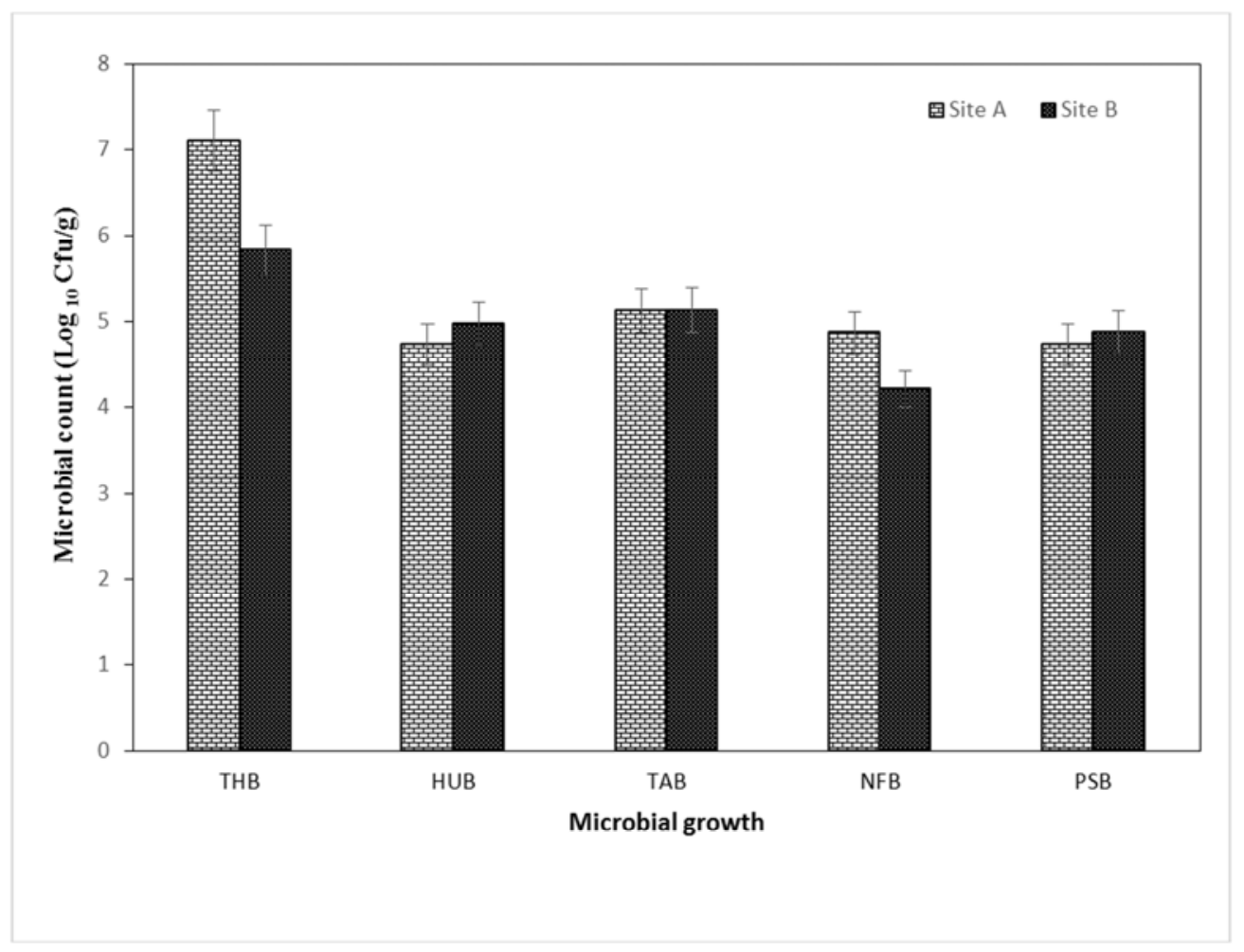

Figure 1. Baseline characterization of crude oil polluted soil samples obtained K-Dere. 


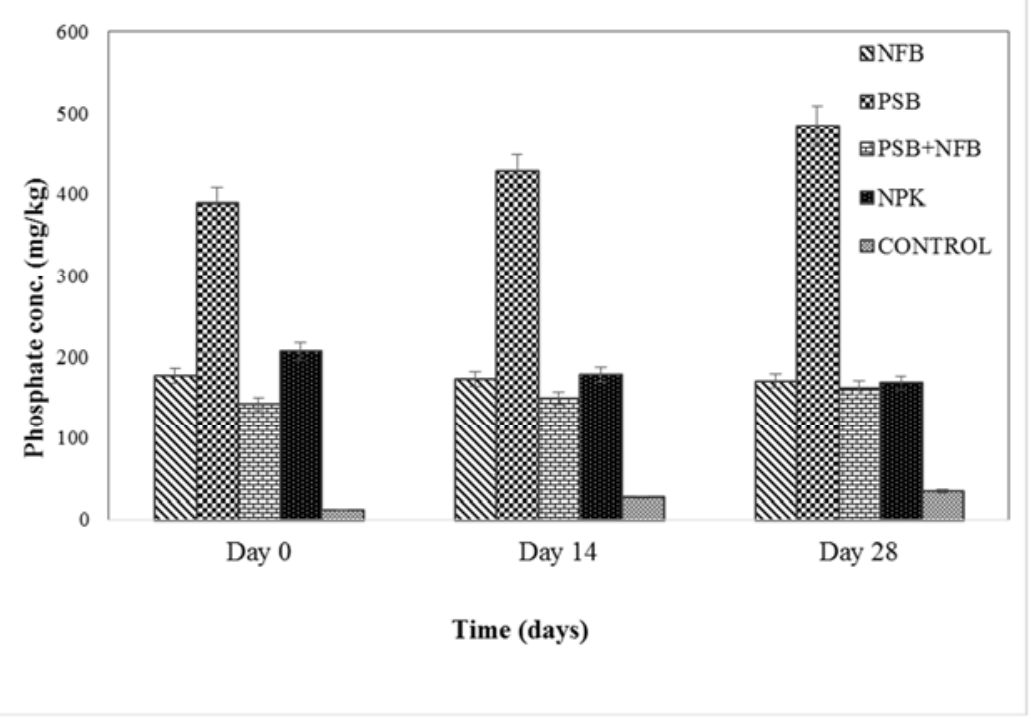

Figure 2. Changes in phosphate level ( $\mathrm{mg} / \mathrm{kg}$ ) in different treatment setups during 28-day.

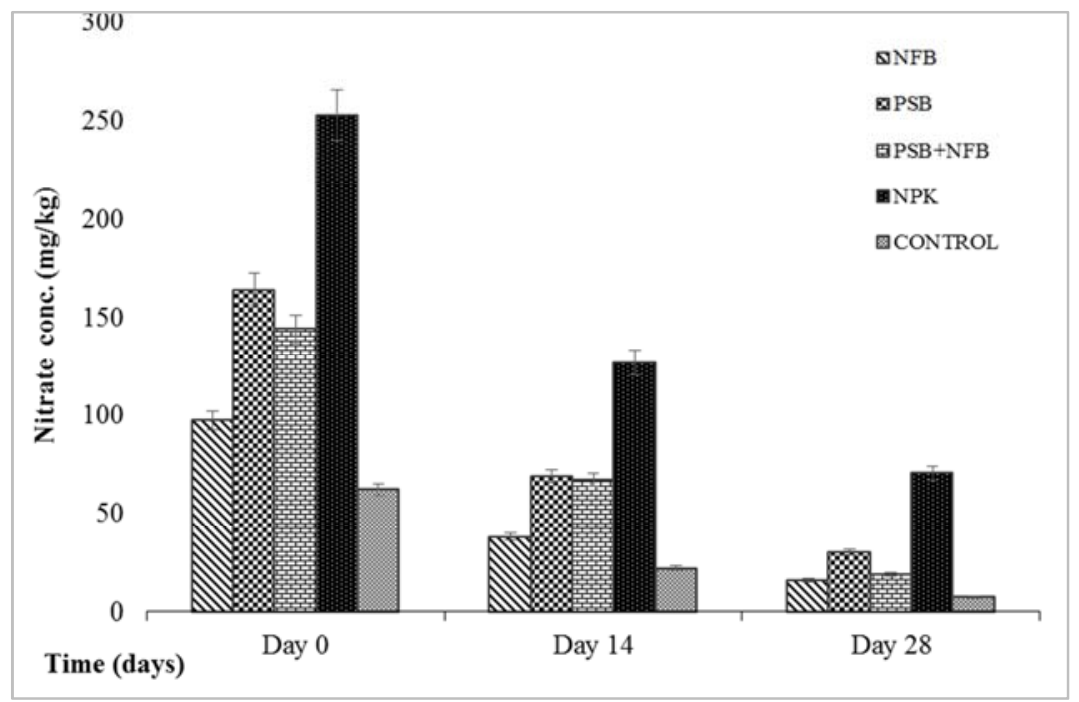

Figure 3. Changes in nitrate ( $\mathrm{mg} / \mathrm{kg}$ ) in various treatments during 28 day.

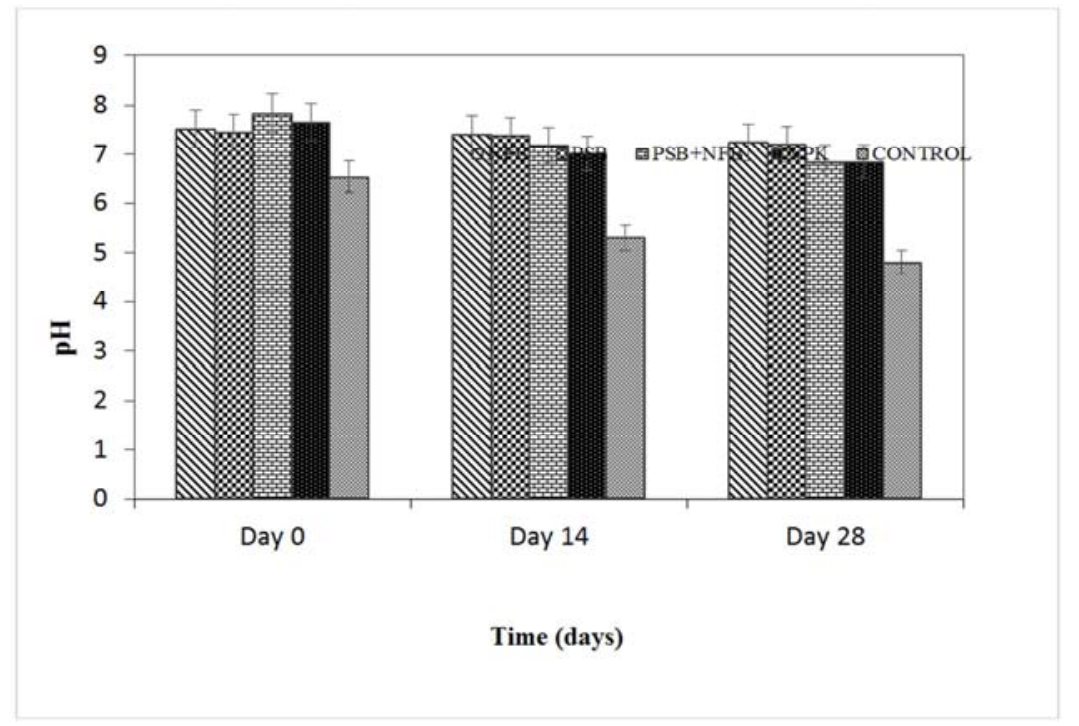

Figure 4. Changes in pH in different treatment setups during 28-day study period. 
The results in Figure 6 described alterations in the TOC. The treatments modified NFB slightly and decreased from 35.69 to $30.57 \mathrm{mg} / \mathrm{kg}$ on $28^{\text {th }}$ day while PSB-amended sample declined from 36.08 to $31.09 \mathrm{mg} / \mathrm{kg}$ on day 28 . The setups NFB+PSB and NPK-amended samples had TOC value of $28.82 \mathrm{mg} / \mathrm{kg}$ and $32.44 \mathrm{mg} / \mathrm{kg}$ on $28^{\text {th }}$ day respectively. However, control had slight reduction from $26.71 \mathrm{mg} / \mathrm{kg}$ to $25.05 \mathrm{mg} / \mathrm{kg}$.

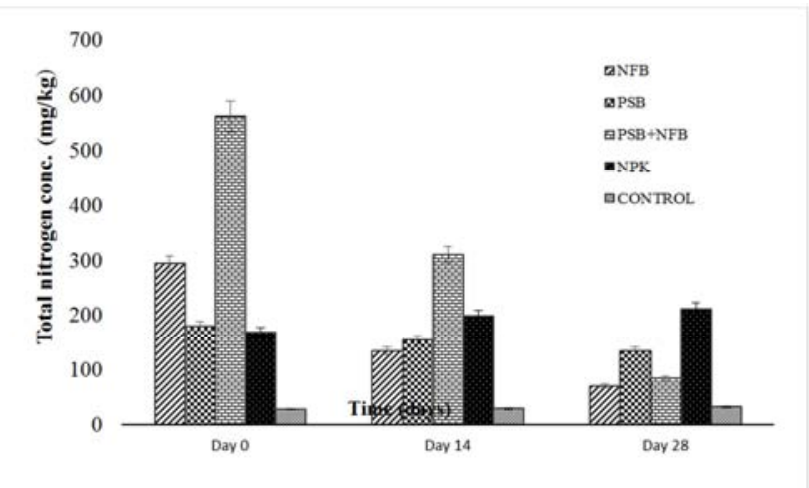

Figure 5. Changes in Total Nitrogen $(\mathrm{mg} / \mathrm{L})$ in different treatment during 28day study.

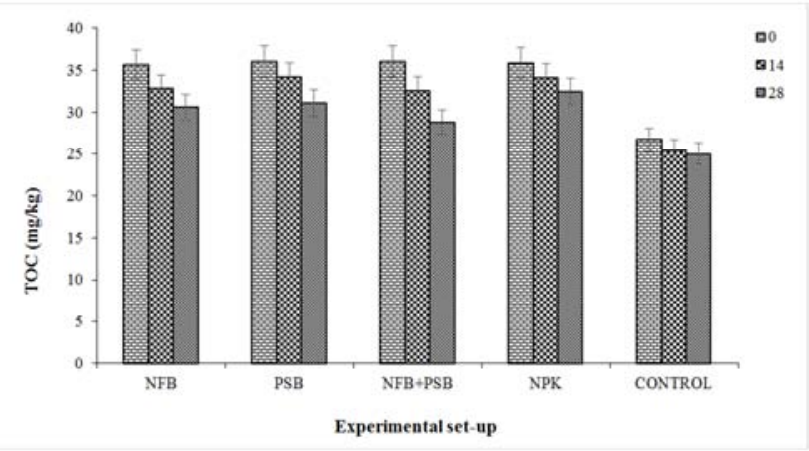

Figure 6. Changes in TOC in different treatment setups during 28-day research period.

The result presented in Figure 7 described alteration in bacterial population during bioremediation study. Notably, PSB-amended sample was observed to have increase in aerobic count from 8.1 to 9.5 and $9.6 \log _{10}$ cfu/g while NPKamended sample was observed to have $7.05 \log _{10} \mathrm{cfu} / \mathrm{g}$ to $7.5 \log _{10} \mathrm{cfu} / \mathrm{g}$ and finally to $8.79 \log _{10} \mathrm{cfu} / \mathrm{g}$ for 0,14 and 28 days respectively. Similarly, there was no particular trend in control set up as it is seen to increase from 6.4 to 6.404 on the $28^{\text {th }}$ day of monitoring. The results presented in Figure 8 revealed a slight increase in HUB count in setup amended with NFB from day 0 to day 14 to day 28 was 5.2, 6.9 and $5.0 \log _{10} \mathrm{cfu} / \mathrm{g}$. The set up amended with NFB+ PSB had increase in microbial population from 4.72 to $7.89 \log _{10} \mathrm{cfu} / \mathrm{g}$ on the $28^{\text {th }}$ day. Set up amended with NPK revealed increase in bacterial population from $5.4 \log _{10}$ cfu/g to $6.8 \log _{10} \mathrm{cfu} / \mathrm{g}$ on $28^{\text {th }}$ day.

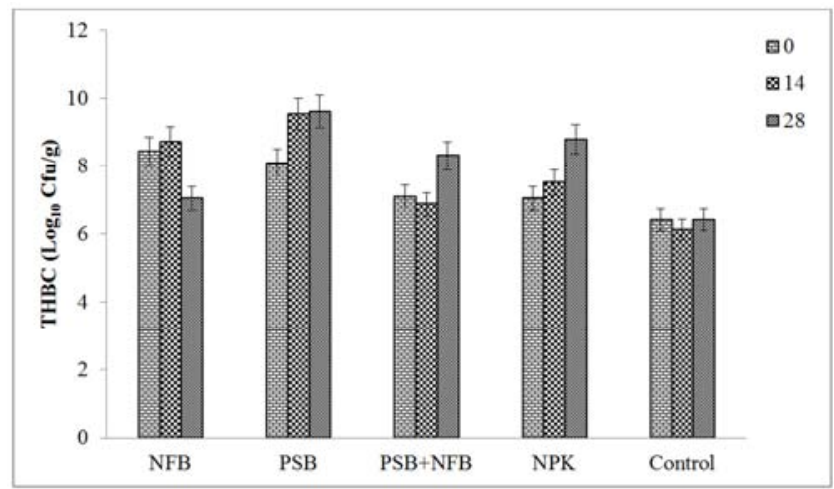

Figure 7. Changes in THBC during bioremediation monitoring study.

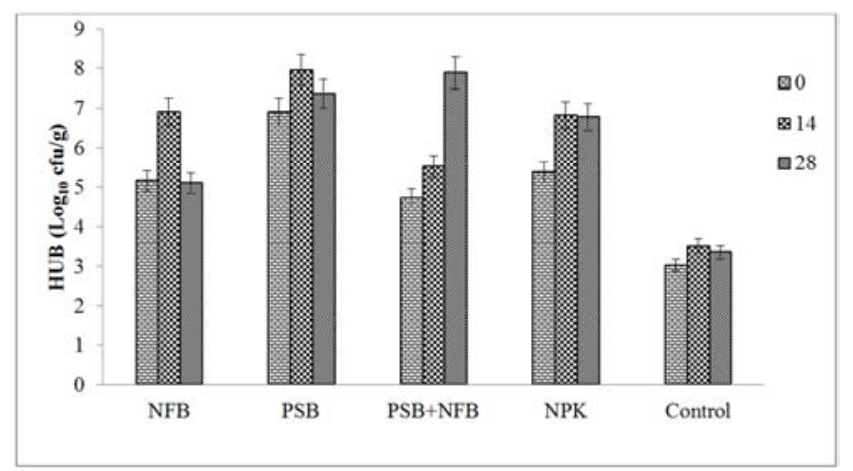

Figure 8. Changes in HUB counts during bioremediation monitoring study.

The results presented in Figure 9 described the growth dynamics of phosphate-solubilizing bacterial flora during bioremediation. The result revealed that PSB amended set up showed sharp decrease from zero days to $28^{\text {th }}$ day from 5.8 $\log 10 \mathrm{cfu} / \mathrm{g}$ to $5.17 \log 10 \mathrm{cfu} / \mathrm{g}$. The set up modified with NPK had increase from 5.0 to $6.9 \log _{10} \mathrm{cfu} / \mathrm{g}$. The result of control revealed that microbial load never showed appreciable trend between initial days to $28^{\text {th }}$ day of this research. The results presented in Figure 10 shows the changes in nitrogen-fixing bacterial counts in the setups amended with NFB for day 0,14 and 28 were 5.0, 6.5 and $5.2 \log _{10} \mathrm{cfu} / \mathrm{g}$. The set up amended with NFB+PSB had increase in microbes population from 5.2 to $6.7 \log _{10} \mathrm{cfu} / \mathrm{g}$ on day 0 and 14 while a decrease was observed on the 28-day as $5.7 \log _{10} \mathrm{cfu} / \mathrm{g}$. NPK amended set up had an increase from 5.0 to $6.0 \mathrm{Log} 10 \mathrm{cfu} / \mathrm{g}$ and later declinedto 5.3 on $28^{\text {th }}$ day. The result from control revealed that microbes load from initial day increased and slightly decreased before 28-day.

The TPH is presented in Figure 11. The results from crude polluted soil modified using NFB bio-fertilizer suggest reduction in TPH from $8987.5742 \mathrm{mg} / \mathrm{kg}$ to $193.7225 \mathrm{mg} / \mathrm{kg}$. Furthermore, samples treated with PSB bio-fertilizer alone reduced from $8987.5742 \mathrm{mg} / \mathrm{kg}$ to $511.1189 \mathrm{mg} / \mathrm{kg}$, samples amended with NFB and PSB bio-fertilizers declined from $8987.5742 \mathrm{mg} / \mathrm{kg}$ to $226.7071 \mathrm{mg} / \mathrm{kg}$. The NPK and control samples reduced from $8987.5742 \mathrm{mg} / \mathrm{kg}$ to $713.0582 \mathrm{mg} / \mathrm{kg}$ and $8987.5742 \mathrm{mg} / \mathrm{kg}$ to $5876.2402 \mathrm{mg} / \mathrm{kg}$ respectively. 


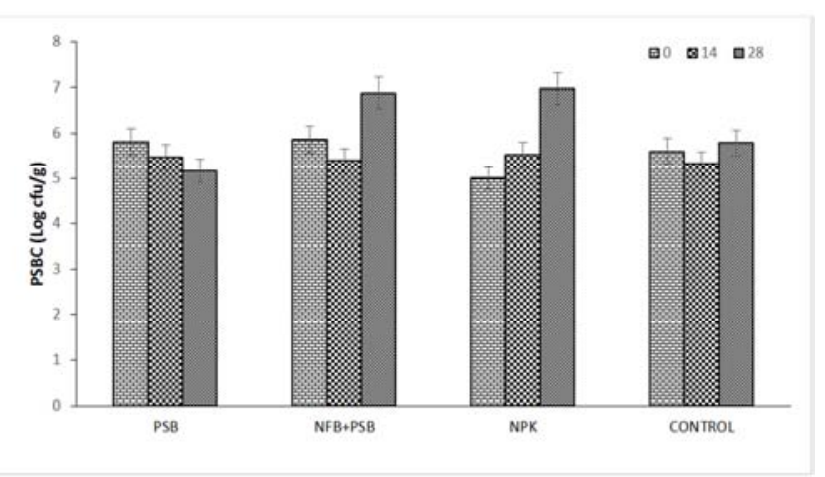

Figure 9. Changes in PSB counts during remediation study.

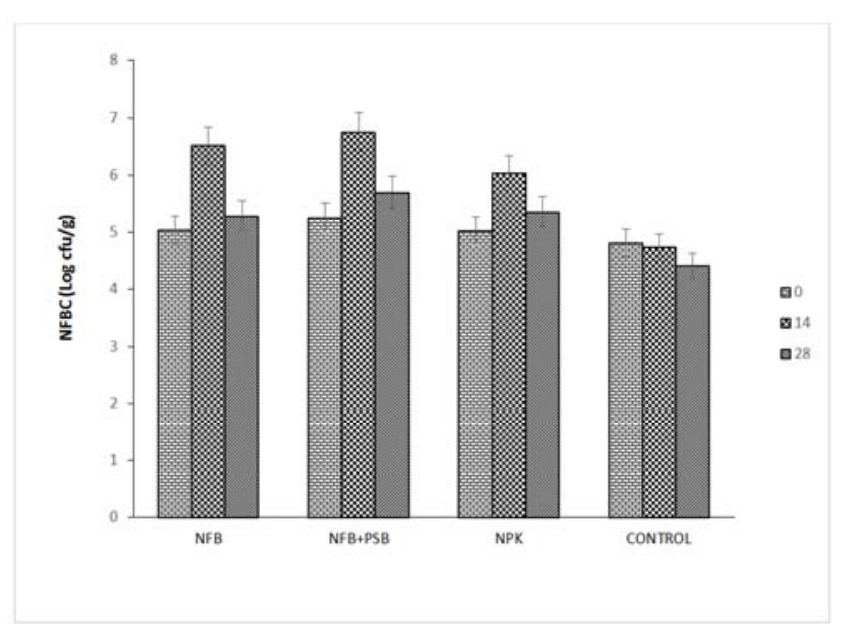

Figure 10. Changes in NFB counts during remediation study.

The results presented in Figure 12 describe the percentage removal of TPH in setups NFB and PSB had a reduction of $97.8 \%$ and $94.3 \%$ respectively. The NFB+PSB amended sample had TPH declined of $97.4 \%$ while NPK and control had decreased to $92.1 \%$ and $34.6 \%$ respectively. The results in Figure 13 described the growth characteristics of maize plants on different bio-fertilizer concentrations.

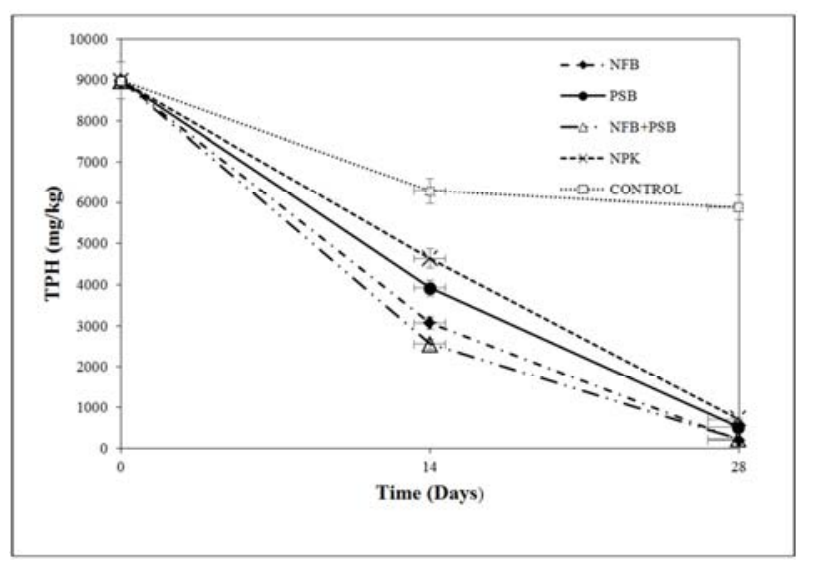

Figure 11. Changes in TPH of soil from different treatments during research period.

The treatments varied with different concentrations of remediated soil and biofertilizers (NFB, PSB and $\mathrm{NFB}+\mathrm{PSB}$ ). The result revealed that NFB treatment had the best seed germination from the initial day 6 to $12^{\text {th }}$ day with concentration ratio of 25:75 with growth height of 20 and 32 $\mathrm{cm}$ respectively. Meanwhile, concentration of 100:0 had retarded growth from 8 to $15 \mathrm{~cm}$ on 12-day.

The PSB treatment revealed the seed growth in the concentration ratio of 25:75 observed the highest growth of 10 to $30 \mathrm{~cm}$ on the 12-day while the set-up concentration ratio of 100:0 was $18 \mathrm{~cm}$ to $23 \mathrm{~cm}$ respectively. The results for mixed NFB+ PSB treatment indicated that seed growth in the ratio of 25:75 showed highest growths from 18 to $31 \mathrm{~cm}$ while no seed growth was witnessed in 100:0 concentration ratio.

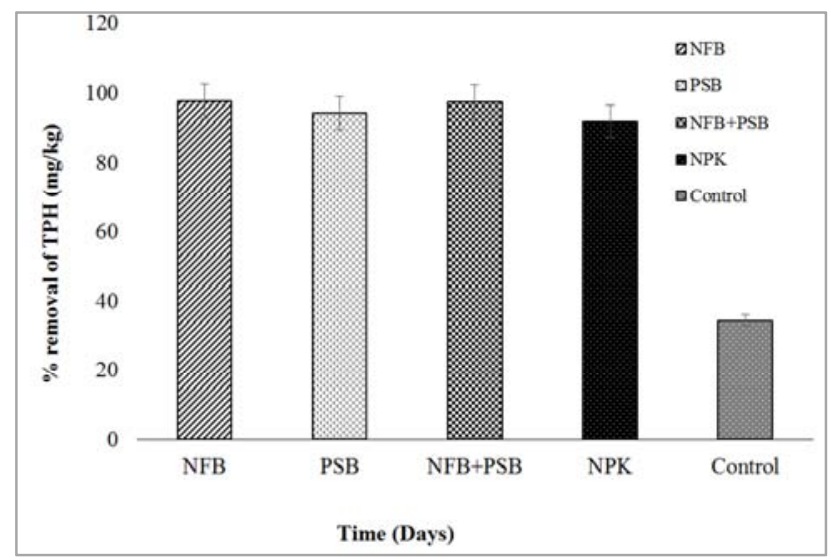

Figure 12. Percentage removal of TPH from soil obtained from various treatments.

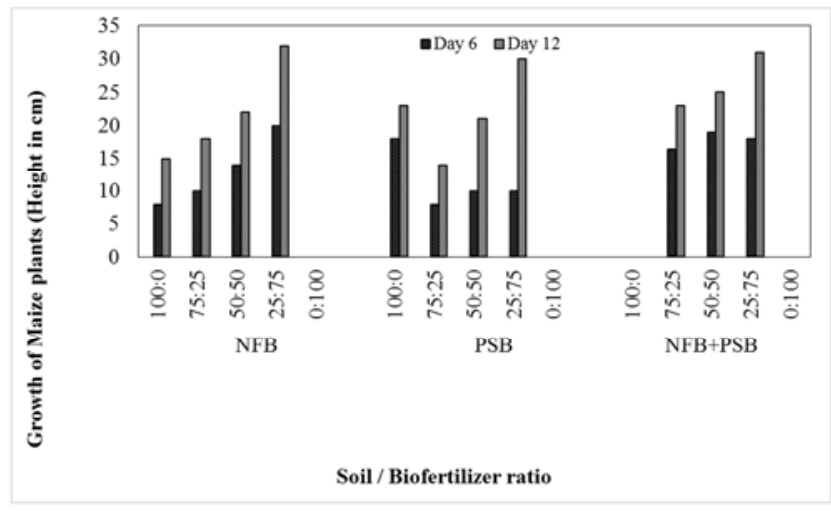

Figure 13. Growth characteristics of maize plants in different biofertilizerconcentrations.

The molecular characteristics of the bacterial isolates after being analysed on agarose gel electrophoresis are presented in Plate. The genes were amplified on the gel. Isolate with codes PSBGB-10, NFGB-8, PSBGB-4 and NFGB-11. The isolates were observed to have bend size of $1.6 \mathrm{kbp}$ on $16 \mathrm{~S}$ universe primers. Isolate NFGB-8was observed to have a 99\% with Azotobacter chroococcum. The PSBGB-10 was observed to have a $98 \%$ similarity with Bacilllusfirmus. Lane 1: DNA maker; Lane 2 and 3: negative and positive controls; Lane 4 and 5: nitrogen-fixing bacteria; Lane 6 and 7: phosphate-solubilizing bacteria. Primer set used $=27 \mathrm{~F}$ $\left(5^{1}\right.$ AGAGTTTGATCMTGGCTCAG- $3^{1}$ ) and 1492R $\left(3^{1}\right.$ GGGTTACCTTGTTACGACTT $\left.5^{1}\right)$. Neighbour- 
combining phylogenetic tree of isolates NFB-8, NFB-11, PSB-4 and PSB-10 are presented in Figure 14.

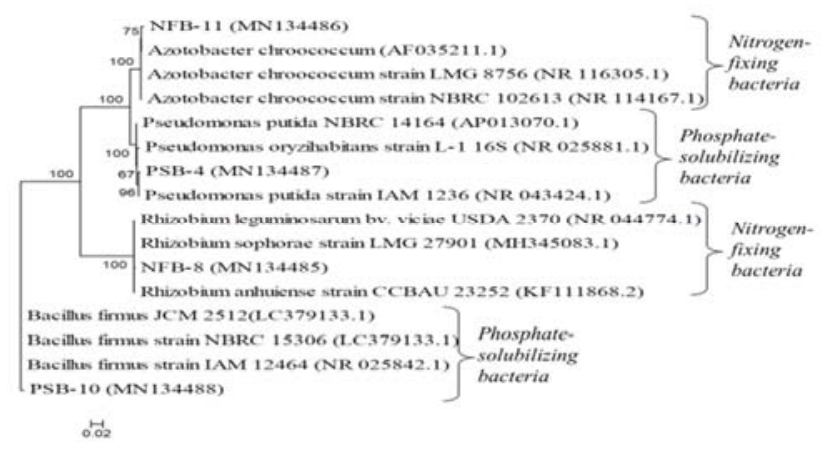

Figure 14. Neighbour-combining phylogenetic tree of isolates $N F B-8, N F B$ 11, PSB-4 and PSB-10 made by MEGA 6.0 [17]. Bootstrap values of $>50 \%$ (based on 1500 replicates) are given in the nodes of the tree. Nucleotide substitution mode used was Jukes and Cantor. NCBI accession numbers are given in parentheses.

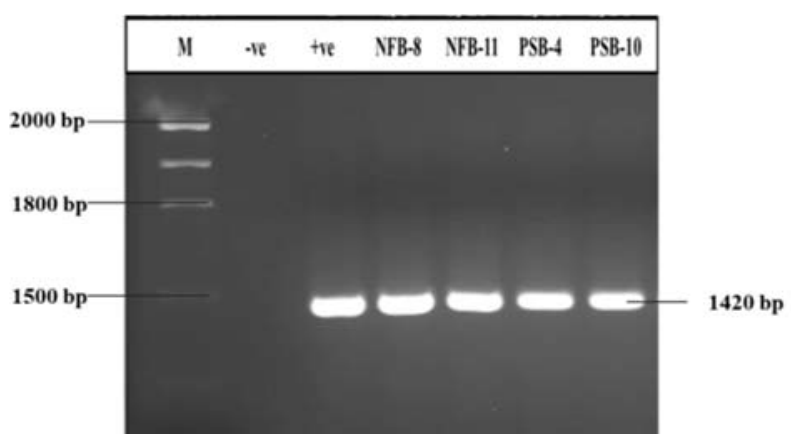

Figure 15. PCR amplification images of the $16 S$ rRNA gene bands of the $N F B$ and $P S B$.

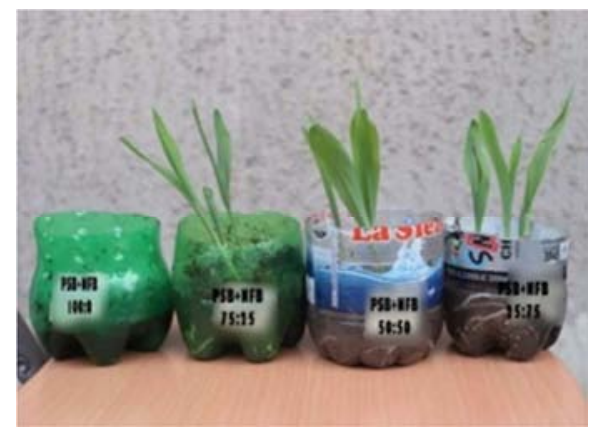

Figure 16. Cultivated maize plant using various concentrations of nitrogenfixing and phosphate-solubilizing biofertilizer (day 6).

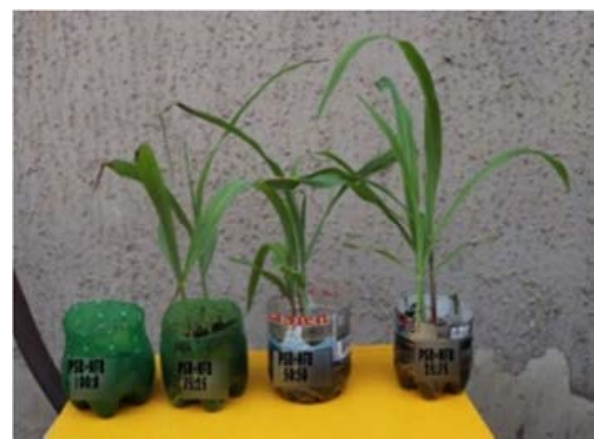

Figure 17. Cultivated maize plant growing best in higher concentration of nitrogen-fixing and phosphate-solubilizing biofertilizer (day 12).

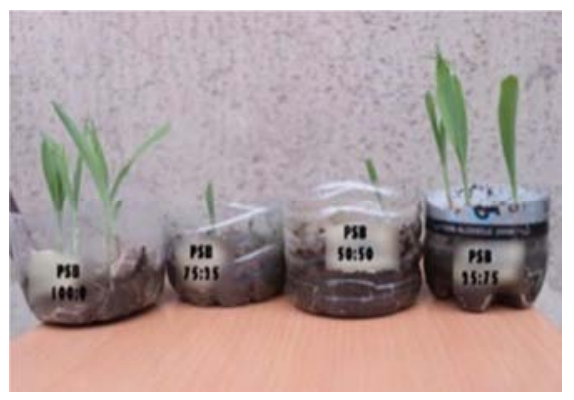

Figure 18. Cultivated maize plant using different concentrations of phosphat solubilizing biofertilizer on day 6 .

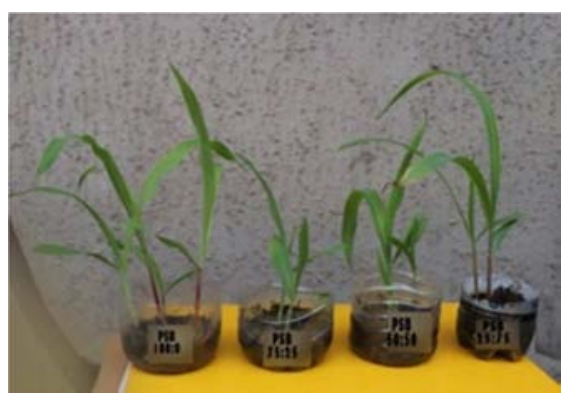

Figure 19. Cultivated maize plant growing best in higher concentration of phosphate solubilizing biofertilizer on day 12.

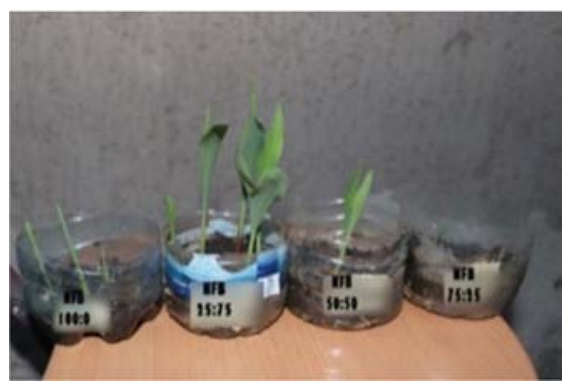

Figure 20. Cultivatied maize plant using different concentrations of nitrogen-fixing biofertilizer on day 6.

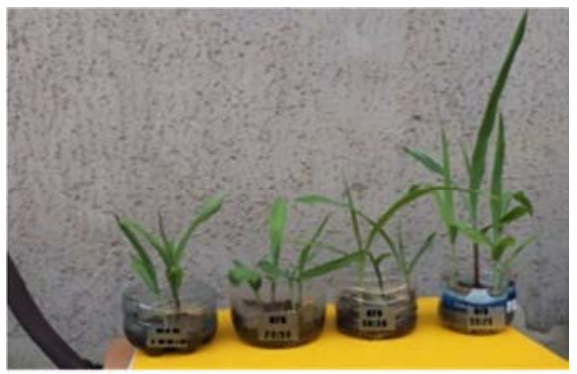

Figure 21. Cultivated maize plant growing best in higher concentration of nitrogen-fixing biofertilizer on day 12.

\section{Discussion}

In this study, bioremediation of crud polluted soil using bio-fertilizer from phosphate-solubilizing and nitrogen-fixing bacteria was examined. Five set ups were used with varying bio-stimulation conditions in crude polluted area. The basic physicochemical and microbiological features of crude polluted soil sampled was observed to have a $\mathrm{pH}$ of $6.5 \pm 0.169$, temperature $28 \pm 0.6^{\circ} \mathrm{C}$ moisture level of 0.16 
$\pm 0.01 \%$, Electrical conductivity $3.6 \pm 0.25 \mu \mathrm{s} / \mathrm{cm}$, nitrate 86.2 $\pm 0.35 \mathrm{mg} / \mathrm{kg}$, phosphate $34.8 \pm 0.7 \mathrm{mg} / \mathrm{kg}$, sulphate $24.1 \pm 0.5$ $\mathrm{mg} / \mathrm{kg}$, TOC $14.18 \%$.

The heterotrophic bacteria number of $1.58 \times 10^{7}$ $\pm 0.205 \mathrm{cfu} / \mathrm{g}$, total fungal count of $3.9 \times 10^{6} \pm 0.004 \mathrm{cfu} / \mathrm{g}$, HUB number of $7.9 \times 10^{4} \pm 0.170 \mathrm{cfu} / \mathrm{g}$, nitrogen-fixing bacteria number $7.4 \times 10^{4} \pm 0.162 \mathrm{cfu} / \mathrm{g}$ and phosphatesolubilizing bacteria number $5.3 \times 10^{4} \pm 0.105 \mathrm{cfu} / \mathrm{g}$ (Table 1). These values suggest that crude polluted soil was loaded with physicochemical parameters and a vast microbial diversity. Furthermore, presence of these highly polluted soils can induce loss in viability of cells and reduction in microbe's population and thereby retarding indigenous flora which could thereby enhance the possible degradation of polluted soil. These values compared with findings from Orhorhoroet al. [18] who reported $\mathrm{pH}$ of 6.38 and moisture level 16.48 . The $\mathrm{pH}$ of crude polluted area was slightly neutral, which suggest it could allow bacteria flora growth. These suggest that crude polluted area had variable acidity level.

The low water amount equally indicatespoor bioavailability of crude components to microbial load. The TPH content of the soil was $8987.5742 \pm 0.00 \mathrm{mg} / \mathrm{kg}$ and THC of $6000 \pm 0.00 \mathrm{mg} / \mathrm{kg}$ suggest fraction of hydrocarbon were laden in polluted area as spent material, these corresponds with report of Ayotamuno et al. [19] who reported 69372 $\mathrm{mg} / \mathrm{kg}$, which is higher than result obtained from this study, the TPH content suggest high load of contaminants of health concern. Bacterial isolates utilized are identified as Azotobacter sp., Rhizobium sp., Pseudomonas sp. and Bacillus sp. using their morphological, bio-chemical and molecular characteristics. These bacteria were formally reported as putative hydrocarbon mortifying bacteria $[20,21$, 22]. The role of microorganisms in hydrocarbon dmortification is significant in contaminant removal and detoxification and this may be attributed to bacterial induced enzyme system and adaptation due to pre-exposure to hydrocarbon pollutants. THB count of polluted area in site A was $7.12 \log _{10} \mathrm{cf} / \mathrm{g}$ while sample obtained from site B was $5.82 \log _{10} \mathrm{cf} / \mathrm{g}$. The HUB count obtained was $4.7 \log _{10} \mathrm{cf} / \mathrm{g}$ and $4.9 \log _{10} \mathrm{cf} / \mathrm{g}$ for site $\mathrm{A}$ and $\mathrm{B}$ respectively. Total aerobic bacterial count was fairly the same in both polluted soil samples 5.12 $\log _{10} \mathrm{cf} / \mathrm{g}$ and $5.25 \log _{10} \mathrm{cf} / \mathrm{g}$ for site A and B. Shamanet al. [23] reported a count range of $8 \times 10^{3}-4.8 \mathrm{x}$ $10^{8} \mathrm{cfu} / \mathrm{g}$ for bacteria count for polluted soil in bio-reactor set up. In related study, Nwogu et al. [24] reported $3.4 \times 10^{5}$ $2.7 \times 10^{6}$. Nitrogen-fixing bacteria number was 4.87 and 4.21 $\log _{10} \mathrm{cf} / \mathrm{g}$ for site $\mathrm{A}$ and $\mathrm{B}$ while phosphate-solubilizing bacteria number was 4.73 and $4.88 \log _{10} \mathrm{cf} / \mathrm{g}$ respectively.

Changes in nitrates and phosphate level which are key sources of ion needed for exchange of reducing agents and oxidizing agents were monitored throughout the study. The nitrate contents for day zero were 97.46, 164.18, 143.9, 252.91 and $62.17 \mathrm{mg} / \mathrm{kg}$ for the setups NFB, PSB, NFB+PSB, NPK and Control, respectively and after day 28, the values had decreased to $15.94,30.43,18.98,70.53$ and $7.30 \mathrm{mg} / \mathrm{kg}$. By day 28 , more rapid decline in nitrate content was observed across the bio-stimulated crude polluted soils.
The phosphate content for day 0 were $177.5 \mathrm{mg} / \mathrm{kg}$ for NFB, $389.07 \mathrm{mg} / \mathrm{kg}$ for PSB, $142.41 \mathrm{mg} / \mathrm{kg}$ for NFB+PSB, 207.16 $\mathrm{mg} / \mathrm{kg}$ for NPK and $12.22 \mathrm{mg} / \mathrm{kg}$ for the Control.

The highest phosphate content was observed at day 14 . Similarly, Ogugbueet al. [10] reported increased nitrate and phosphate concentrations in experimental setups over a bioremediation study period and their report is similar to this findings. The reduction in nitrates and phosphates were significant after 2 weeks of this experiment. This outcome agree with Ayotamuno et al. [19] who suggested that decline level of nutrient supplement, may have stimulated response in increase in bacteria population. A PH change over this bioremediation research was monitored in different set-ups. $\mathrm{PH}$ condition affects nutrient availability. During this research, $\mathrm{pH}$ of soil modified with NFB changed from $\mathrm{pH} 7.5$ to 7.4 and 7.2. This $\mathrm{pH}$ range is within the alkaline level reported by Nwoguet al. [24]. Meanwhile, $\mathrm{pH}$ in the NFB+PSB setup decreased from slightly alkaline to neutral throughout the study. These results agreed with the findings of Ogugbue et al. [10], who stated that shift in $\mathrm{pH}$ value in neutrality direction might be because of extinction of crudebased hydrocarbons present in polluted area since neutral level of $\mathrm{pH}$ is optimum for bacteria metabolism and growth. Neutral $\mathrm{pH}$ condition favored ability of used bacteria to degrade crude.

The $\mathrm{pH}$ in control setup reduced from 6.5 to 4.8 . This concord with work of Ayotamunoet al. [19] who reported that control $\mathrm{pH}$ of set up declined during bio-remediation in crude polluted area. Changes in population density of different microbial groups in soil samples were determined by numbering of total cultivable heterotrophic bacteria and total cultivable hydrocarbon using bacteria (HUB).In set ups NFB and PSB, there was gradual increase in HUB population with time suggesting that cells utilized hydrocarbon as source of carbon and energy. The results also suggest that the gradual increase in THUB population might be linked to nutrient availability and subsequent decrease in number as nutrients were depleted.

For example, in setups NFB, the HUB population increased from $5.2 \log _{10} \mathrm{cfu} / \mathrm{ml}$ on zero days to $6.9 \log _{10} \mathrm{cfu} / \mathrm{ml}$ on the day 14. Meanwhile the counts of THUB reduced to $5.0 \log _{10} \mathrm{cfu} / \mathrm{g}$ on the day 28 . This reduction in THUB counts might be linked to decline in hydrocarbon/pollutants concentration (carbon and energy source). This decrease in microbial number and population after day 28 might be linked to nutrients depletion, complete crude oil metabolism as they were added once, and toxic metabolites accumulation. The results are in line with those obtained by Onifade and Abubaker [25], who reported a sharp reduction in microbial counts and attributed this decline to nutrient limitation.

Furthermore, in the set ups NFB + PSB and NPK, the HUB population increased over time, might be because of nutrient availability/utilization as bio-stimulation. More so, in the NFB+PSB treatment population of HUB increased from $4.72 \log _{10} \mathrm{cfu} / \mathrm{ml}$ on the day zero to $7.89 \log _{10} \mathrm{cfu} / \mathrm{ml}$ by day 28 and there was appreciable $(\mathrm{P}<0.05)$ rise in microbe population between day 0 and 28 . The increase in population 
of HUB could be attributed to role of bio-stimulation and toutilizing nutrient by bacteria isolates [26]. The rapid growth of HUB in NFB, PSB, NFB+PSB and NPK might be linked to modified nutrients in treatment set-ups.

The nutrients which are particularly potassium, nitrogen, and phosphorus perhaps stimulated microbe's growth and permitted microbes to produce necessary and crucial enzymes needed to breakdown petroleum-based hydrocarbon contaminants since they are main foundation of life [27]. Although, HUB were present in polluted area their numbers might not be sufficient to commence effectual contaminated soil remediation. Therefore, activities of HUB are stimulated by supplying or inputting of carbon, nitrogen, and phosphorus which are used by these modifying microbes for their metabolic performance [28]. Previous research showed that nitrogen is crucial for cell-based protein and cell-wall formation while phosphorus is crucial for nucleic acids, ATP formation and cell membrane [29]. The bioremediation study involves phosphate-solubilizing bacteria shows increase phosphate concentration with proliferate increases in biomass of organism in NFB+PSB and NPK samples. The initial rise in soil available phosphorus was because of ability of organism to solubilize phosphate present in soil. According to Debojyotic et al. [6] that started thatPSB are very crucial in solubilization to insoluble phosphate by release of organic acids. Moreover, the sample PSB reveals progressive decreases after initial day because of fact that they used hydrocarbon as metabolite in building biomass. The isolated organisms Pseudomanas and Bacillus spp. play active roles in bioremediation of crude polluted area by degrading hydrocarbon components. This result agrees with findings from Abu and Ogiji [13] and Zhu et al. [30] who showed that phosphate was used by microbes during bioremediation research.

It was established that phosphorus availability limits microbe's degradation for hydrocarbon. Chikere et al. [31] reported on ability of Pseudomonas sp. and Bacillus sp. to use crude as carbon source. They possess genes which code enzymes like catechol di-oxygenase, alkane monooxygenase and alkene sulfonate mono-oxygenase thathelp in breaking down hydrocarbon chains. The control sample in this research has no appreciable increase in microbial population which has linked to toxicity of crude oil components. During remediation on crude polluted soil, samples treated with nitrogen-fixing bacteria was noticed to have gradual reduction of hydrocarbon contents between day 14 and $28 \mathrm{in}$ nitrogen-fixing bacterial (NFB) bio-fertilizer from 6.2 $\log _{10} \mathrm{cf} / \mathrm{g}$ to $5.2 \log _{10} \mathrm{cfu} / \mathrm{g}$, NFB+PSB-bio-fertilizers from 6.7 $\log _{10} \mathrm{cfu} / \mathrm{g}$ to $5.7 \mathrm{Log}_{10} \mathrm{cf} / \mathrm{g}$, NPK from $6.0 \log _{10}$ to 5.3 $\log _{10} \mathrm{cf} / \mathrm{g}$.

The isolated organisms Azotobactersp. and Rhizobium sp. carried nitrogenase enzyme, capable to fix atmospheric nitrogen into the soil. According to Swain and Abhijita [32] both organisms act as bio-fertilizer in supplying macronutrient. This observation agrees with Ogugbueet al. [10] that started that hydrocarbon-based polluted soil with modified microbes like nitrogen-fixing bacteria aids in co- metabolism and nitrogen fixation to autochthonous bacteria which aid in availing needed nitrogen that would improve degradation of hydrocarbons.

The findings of Agary and Ogunlaye [33] and Nwoguet al. [24] revealed that their numbers in soil are increased by bioaugmentation to speed up biodegradation rate. Biodegradation kinetics studies revealed that degradation efficiency for PSB-amended sample was $94.3 \%$ while NFB and NFB+PSB-amended plots were $97.8 \%$ and $97.5 \%$ respectively. However, the positive control was $92.1 \%$ while the negative control (Un-amended) was $34.6 \%$. Similarly, the half-life of about 5 days was reported for NFB and NFB+PSB. PSB-alone had a half-life of 7days. Furthermore, NPK-amended set had a half-life of 8.0 days while the unamended control had a half-life of 45 days.

In a related study Qin et al. [34] carried a similar work using biochar to deliver phosphates in a bioremediation and reported $84.8 \%$ loss in the TPH of the petroleum polluted soil. This report agrees with result from this study that nitrate and phosphates which deliver limiting nutrient to HUB community from exogenous sources could be functional in bio-removal of pollutants. In related research, Wu et al. [35] in a study where they employed bio-stimulation and bioaugmentation in bioremediation of crude polluted area reported $60 \%$ loss of TPH during their 40 day study duration.

This was in tandem with the report of this current research suggesting that delivering microbes cultures in development of bio-augmentation approach is pivotal to removal of TPH and contaminants of concerns [36]. The PAHs were observed to have reduced by $94.8 \%$ by the application of $50 \mathrm{~g}$ nitrogen-fixing bacterial biofertilizer. Other biofertilizers PSB and NFB+PSB were weighed $50 \mathrm{~g}$ also declined the PAHs to 96.0 and $98.1 \%$. There is sharp increase in degradation of the PAHs in the three setups. The control only decreased by $25.3 \%$ component like benzene, 1, 2, 3trimethyl-, naphthalene, anthracene, pyrene, benz (a) anthracene. This finding agrees with the results of Sutherland et al. [37] who reported presence of 1-methyl naphthalene, phenonthrene, fluorenthene, pyrene, chrysene, 2-methyl naphthalene, acenepthylene, acenephthene, fluorane, anthraene, benzo (a) anthraene, benzo (b) fluorenthene, benzo $(\mathrm{k})$ fluorenthene, benzo (a) pyrene and indanol $(1,2,3$ cd)pyrene. At the end of day 14, NFB: diben $(a, h)$ anthracene, indeno $(1,2,3-\mathrm{cd})$ pyrene, benzo $(\mathrm{g}, \mathrm{h}, \mathrm{i})$ perylene, PSB: benzo $(\mathrm{k})$ fluoranthene, benzo (a) pyrene, diben $(\mathrm{a}, \mathrm{h})$ anthracene, indeno (1, 2, 3-cd) pyrene, benzo (a) pyrene, benzo $(\mathrm{g}, \mathrm{h}, \mathrm{i})$ perylene. NFB+PSB: benzo $(\mathrm{k})$ fluoranthene, benzo (a) pyrene, diben $(\mathrm{a}, \mathrm{h})$ anthrecene, indano $(1,2,3-\mathrm{cd})$ pyrene, benzo $(\mathrm{g}, \mathrm{h}, \mathrm{i})$ perylene.

The toxicity of the biofertilizer on routinely grown crop such as maize was studied. The toxicity testing involved 5 set-ups with ratios of remediated soil to biofertilizer of $0: 100$, 25:75, 50:50, 75:25, and 100:0, and these were performed for the different treatments. There was no growth of maize seeds planted in NFB+PSB in concentration of 100:0 while growth was observed forsame concentration in NFB and PSB setups. Luxuriant growth ofmaize plants were recorded in 25:75 
ratios for all the setups. This indicated that adequate nutrients were available for growth of maize seeds and that at $75 \%$ concentration; the bio-fertilizer was non-toxic to the maize seedlings.

The healthy growth is linked to uptake of crucial nutrients through well-developed root system and manifest on leaves as earlier reported [38-40]. The concentration of 0:100 bio-fertilizers in allsetups (NFB, PSB, NFB+PSB) recorded no growth of seeds. The rate of moisture level cause asphyxiation ofseeds and clogging of bio-fertilizer air pores to prevent growth. Applying bio-fertilizer for agricultural practices reduces risk of toxicity to environment. Odokuma and Ibor [5] reported that planting of the seed at once with fertilizer application may have accounted for absence of growth. This is expected since traditionally fertilizers are applied to farmlands weeks and months before planting [41].

\section{Conclusion}

Bio-stimulation of indigenous microbial communities was achieved by nutrient amendment strategies. The remediation outcome revealed that the most target limits were achieved within four weeks of the study. Total petroleum hydrocarbon and hydrocarbon contents were reduced to $97.8 \%$. These were achieved by amending the polluted soil with nitrogenfixing and phosphate-solubilizing bio-fertilizers. Phosphate, nitrogen and nitrate were reduced during the study using the $50 \mathrm{~g}$ of the substrates.

The $\mathrm{pH}$ of the soil matrix was buffered by the nutrient amendment with both nitrogen-fixing and phosphatesolubilizing bio-fertilizers. This work shows that the biofertilizer contributed to greater percentage reduction of crude-basedhydrocarbon. This occurred when nitrogen-fixing bacteria bio-fertilizer and combination of nitrogen-fixing and phosphate-solubilizing bacterial bio-fertilizer were used. The use of bio-fertilizer provides essential limiting nutrients in enhancing bioremediation on crude oil polluted area in KDere. The concentration ratioof 25:75 (remediated soil / biofertilizer) supports cultivation practices due to the nontoxicity of the biofertilizer.

\section{Recommendations}

Government agencies must be heartened to sponsor field executions for application of bio-fertilizer made with nitrogen-fixing and phosphate-solubilizing bacteria. Biofertilizers from nitrogen-fixing and phosphate-solubilizing bacteria should be providedto farmers for agricultural practices instead of chemical fertilizers. The nitrogenfixing and phosphate-solubilizing acteria (Azotobacterchroococcum, Rhizobium leguminosarum, Bacillus firmus and Pseudomonas putida) isolated in this study when used for crude oil polluted soil amendment, will stimulate indigenous hydrocarbon degraders to utilize hydrocarbon.

\section{References}

[1] Debojyotic, R., Manibrata, P. and Sudip, B. K. (2015). Isolation, identification and characterizationof phosphate solubilizing bacteria from soil and the production of biofertilizer. International Journal Curriculum Microbiol. Application Sci. 4 (11): 808-815.

[2] Gomare, K. S., Mese, M. and Shetkar, Y. (2013). Isolation of Azotobacter and cost effective production of biofertilizer. Indian Journal Applied Research, 3 (5): 54-56.

[3] Vessey, J. K. (2003). Plant growth Promoting rhizobacteria as biofertilizers. Application of Soil Ecology, 225 (2): 571-586.

[4] Stanley, H. O., Maeba, N. S., Gbenekanu, D. K., and Ugboma, C. J. (2018). Crude oil degradation using spent mushroom compost (SMC) of pleurotusflorida. Asian Journal of Advanced Research and Reports, 2 (1): 1-7.

[5] Odokuma, L. O. and Ibor, M. N. (2002). Nitrogen-fixing bacteria enhanced bioremediation of a crude oil polluted soil. Global Journal of Pure and Applied Sciences, 8 (4): 455-468.

[6] Debojyoti, R., Manibrata, P. and Sudip, K. B. (2015). Isolation, identification characterization of phosphatesolubilizing bacteria from soil and the production of biofertilizer. International Journal of Current Microbiology and Applied Sciences, 4 (11): 808-815.

[7] Sandhimita, M., Suvakhan, D., Anwesha, B., Satarupa, B. and Rituparna, D. (2017). Production and application of phosphate-solubilizing bacteria as biofertilizer. International Journal of Environmental and Agricultural Research, 3 (1): 19.

[8] Neal, P. (1995). Teaching sustainable development. Environ. Education, 50: 8-9.

[9] Boopathy, R. (2003). Use of anaerobic soil slurry reactors for the removal of petroleum hydrocarbon in soil International Biodeterioration and Biodegration 52:161-16.

[10] Ogugbue, C. J., Solomon, L. and Olali, I. N. (2017). Enhanced bioremediation of petroleum hydrocarbons in polluted soil augmented with nitrogen-fixing bacteria. Life Science Journal, 14 (1): 82-91.

[11] Walpola, B. C. and Yoon, M. (2013). Isolation and characterization of phosphate solubilizing bacteria and their co-inoculation efficiency on tomato plant growth and phosphorous uptake. African J. Microbiol. Res. 7 (3): 266275.

[12] Okon, Y., Albrecht, L. S. and Burris, H. R. (1977). Methods for growing Spirillumlipoferum and for counting it in pure culture and association with plants. AppliedEnvironmental Microbiology, 33: 85-88.

[13] Abu, G. O. and Ogiji, A. P. (1996). Initial test of a bioremediation scheme for the cleanup of an oil-polluted water body in a rural community in Nigeria. BioresourceTechnology, 58: 7-12.

[14] Holt, G. J., Krieg, N. R., Sneath, A. P., Staley, J. T. and Williams, S. T. (1994). Genus Acetobacterand Gluconobacter. Bergey's Manuel of Determinative Bacteriology, $19^{\text {th }} \mathrm{edn}$. Williams and Wilkens, p71-84. 
[15] United State Environmental Protection Agency (USEPA) (1991). Guidelines for developmental toxicity risk assessment. EPA/600/FR-91/001.

[16] Crepin, J. and Johnson, L. R. (1993). Soil sampling for environmental assessment. In Carter R. M (Ed) Soil Sampling and Methods of Analyses. 765.

[17] Tamura, K., Stecher, G., Peterson, D., Filipski, A. and Knmar, S. (2013). Molecular evolutionary genetics analysis version 6.0. Molecular Biol. \& Evolution, 30: 2725-2729.

[18] Orhorhoro, E., Effiong, E. and Abu, G. (2018). Laboratory-scale bioremediation of crude oil polluted soil using consortia of rhizobacteria obtained from plants in Gokana-Ogoni, Rivers State. Journal of Advances in Microbiology, 9 (1): 1-17.

[19] Ayotamuno, J. M., Kogbara, R. B., Ogaj, O. T. and Probert, D. S. (2006). Bioremediation of a crude oil polluted agricultural soil at Port Harcourt, Nigeria. Appl. Ener. 82: 1249-1257.

[20] Kaplan, C. W. and Kitts, C. L. (2004). Bacterial succession in a petroleum land treatment unit. Applied and Environmental Microbiology, 70: 1756-1777.

[21] Survery, S., Ahmed, S., Subham, A. S., Ajaz, M. and Rasool, A. S. (2004). Hydrocarbon degrading bacteria from Pakistani soil: isolation, identification, screening and genetic studies. Pakistan Journal of Biological Sciences, 7 (9): 1518-1522.

[22] Chikere, B. C. and Ekwuabu, B. C. (2014a). Culturedependent characterization of hydrocarbon utilizing bacteria in selected crude oil-impacted sites in Bodo, Ogoni land, Nigeria. African Journal of Environmental Science and Technology, 8: 401-406.

[23] Sharma, B. S., Riyaz, S. Z., Mrugesh, H. T and Thivakaran, A. G. (2015). Phosphate solubilizing microbes: a sustainable approach for managing phosphorus deficiency in agricultural soils. http://www.springerplus.com/.

[24] Nwogu, T. P., Azubuike, C. C. and Ogugbue, C. J. (2015). Enhanced bioremediation of soil artificially contaminated with petroleum hydrocarbons after amendment with (Goat) manure. Biotechnology Research International, 657349: 1-7.

[25] Onifade, A. K. and Abubakar, A. F. (2007). Characterization of hydrocarbon degrading microorganisms isolated from crude oil contaminated soil and remediation of the soil by enhanced natural attenuation. Research Journal of Biological Sciences, 2 (1): 149155.

[26] Yerushami, L. S., Rocheleau, R., Cimpoia, M., Sarrazin, G., Sunahara, A. (2003). Enhanced bioremediation of petroleum hydrocarbons in contaminated soil. Bior. Journal, 7 (1): 37-51.

[27] Vidali, M. (2001). Bioremediation. An overview. Diparimento di chimica inorganic, Metallorganica, eAnalitica, Universita di Padova Via Loredan, 435128 Padova, Italy.

[28] vanHamme, D. J., Singh, A. and Ward, O. P. (2003). Recent advances in petroleum microbiology. Microbiology and Molecular Biology Reviews. 67: 503-505.

[29] Swindell, C. M., Aelion, C. M. and Pfaender, F. K. (1988). Influence of minerals and organic nutrients anaerobic biodegradation and the adaptation response of surface microbial communities. Applied and Environmental Microbiology, 54 (1): 212-217.
[30] Zhu, X., Venosa, A. D., Suidan, M. T. and Lee, K. (2001). Guidelines for the bioremediation of marine shorelines and freshwater wetlands. Report under a contract with office of Research and Development, US-EPE. Pp 201.

[31] Chikere, B. C. and Ekwuabu, B. C. (2014b). Molecular characterization of autochthonous hydrocarbon utilizing bacteria in oil-polluted site at Bodo community, Ogoni land, Niger Delta, Nigeria. Nigerian Journal of Biotechnology. 27: 28-33.

[32] Swain, H. and Abhijita, S. (2013). Nitrogen fixation and its improvement through genetic engineering. J. Global Bioscience 2: 98-112.

[33] Agarry, E. S. and Ogunleye, O. (2012). Box enhanced design application to study enhanced bioremediation of soil artificially contaminated with spent engine oil using biostimulation strategy. International Journal Energy and Environmental Engineering,

[34] Qin, G., Gong, D., and Fan, M. Y. (2013). Bioremediation of petroleum-contaminated soil by biostimulation amended with biochar. International Biodeterioration and Biodegradation, $85,150-155$.

[35] Wu, M., Dick, A. W., Li, W., Wang, X. and Chen, L. (2016). Bioaugumentation and biostimulation of hydrocarbon of hydrocarbon degradation and the microbial community in a petroleum-contaminated soil. Intl. Biodet. \&Biodeg. 107, 158164.

[36] mPeele, A. K. and Kodali, P. V. (2016). Emulsifying activity of a biosurfactant produced by a marine bacterium. 3 Biotechnology, 6 (2): 2-7.

[37] Sutherland, J. B., Rafii, F., Khan, A. A. and Cerniglia, C. E. (1995). Mechanisms of polycyclic aromatic hydrocarbon degradation, in Microbial Transformation and Degradation of Toxic Organic Chemicals, Wiley-Liss, New York, 269-306.

[38] Ogugbue, C. J., C. Mbakwem-Aniebo and L. Solomon (2017). Efficacy of brewery spent grain and rabbit droppings on enhanced ex situ bioremediation of an aged crude oil contaminated soil. Intl. Journal of Applied Microbiol. \& Biotech. Research, 5 (4): 27-39.

[39] Solomon, L., C. J. Ogugbue and G. C. Okpokwasili (2018a). Post remediation assessment of residual hydrocarbons in contaminated soil in Ogoni using gas chromatographic fingerprinting technique and phytotoxicity bioassay. Journal of Petroleum\&Environmental Biotechnology, 9 (2): 367.

[40] Solomon, L., C. J. Ogugbue and G. C. Okpokwasili (2018b). Influence of biostimulation treatment using composted plant biomass on bacterial diversity of an aged petroleum contaminated soil as determined by culture-dependent and 16S rRNA gene PCR-DGGE based identification methods. South Asian Journal of Research in Microbiology, 1 (2): 1-16.

[41] Solomon, L., C. J. Ogugbue and G. C. Okpokwasili (2018c). Inherent bacterial diversity and enhanced bioremediation of an aged crude oil-contaminated soil in Yorla, Ogoni land using composted plant. Journal of Advances in Microbiology, 9 (3): $1-11$. 